\title{
Survival after penetrating Shrapnel to the Heart and Colon: Which Injuries to tackle First?
}

\author{
${ }^{1} \mathrm{M}$ Ezzedien Rabie, ${ }^{2}$ Ricardo Gallo, ${ }^{3}$ Medhat A Refaie, ${ }^{4}$ Mansour Al Asmary
}

\section{ABSTRACT}

Aim: To report on the clinical course of a patient who received penetrating shrapnel to the heart and colon.

Background: Penetrating missiles to the heart is a highly lethal incident, particularly, when associated with other serious injuries.

Case report: This is the case of a 29 -year-old male soldier, who sustained multiple shrapnel injuries caused by an explosive device in the war zone. Shrapnel penetrated the cecum and another lodged in the interventricular septum of the heart. Surprisingly, the patient was stable enough to undergo a staged procedure, where he was subjected to limited right hemicolectomy first, followed by open heart surgery to extract the cardiac shrapnel twelve hours later. His convalescence was uneventful and was discharged in a good condition.

Conclusion: With timely intervention and close collaboration between the concerned clinicians in specialized centers, patients with penetrating shrapnel to vital structures, including the heart, could have a successful outcome.

Clinical significance: Critical thinking is needed to prioritize which injuries to deal with first, in patients with near lethal injuries.

Keywords: Cardiac, Case report, Colon, Penetration, Shrapnel.

How to cite this article: Rabie ME, Gallo R, Refaie MA, Asmary MA. Survival after penetrating Shrapnel to the Heart and Colon: Which Injuries to tackle First? Panam J Trauma Crit Care Emerg Surg 2017;6(3):209-213.

Source of support: Nil

Conflict of interest: None

\section{RESUMEN}

Objetivo: Reportar el curso clínico de un paciente que recibió esquirlas penetrantes al corazón y colon.

Historia: Misiles penetrantes en el corazón es un incidente altamente letal, especialmente cuando se asocia con otras lesiones serias.

\footnotetext{
${ }^{1,2}$ Consultant, ${ }^{3}$ Senior Registrar, ${ }^{4}$ Resident

1,4Department of Surgery, Armed Forces Hospitals Southern Region, Khamis Mushait, Aseer, Kingdom of Saudi Arabia

${ }^{2,3}$ Department of Cardiac Surgery, Armed Forces Hospitals Southern Region, Khamis Mushait, Aseer, Kingdom of Saudi Arabia

Corresponding Author: M Ezzedien Rabie, Consultant Department of Surgery, Armed Forces Hospitals Southern Region, Khamis Mushait, Aseer, Kingdom of Saudi Arabia Phone: +966507753692, e-mail: ezzedien@hotmail.com
}

Descripción del caso: un soldado masculino de 29 años de edad, que sufrió múltiples heridas de esquirlas causadas por un artefacto explosivo en la zona de guerra. Una de las esquirlas penetró el intestino ciego y otra alojada en el septo interventricular del corazón. Sorprendentemente, el paciente estaba lo suficientemente estable como para someterse a un procedimiento de etapas, donde fue sometido a hemicolectomía derecha limitada en primer lugar, seguido por cirugía a corazón abierto para extraer la esquirla cardiaca doce horas más tarde. Su convalecencia fue sin incidentes y fue dado de alta en buenas condiciones.

Conclusión: Con la intervención oportuna, y estrecha colaboración entre los médicos tratantes, en centros especializados, pacientes con esquirlas penetrantes a estructuras vitales, incluyendo el corazón, puden tener un resultado exitoso.

Significado clínico: Con pensamiento crítico, es necesario priorizar qué lesiones tratar primero, en pacientes con lesiones letales.

Palabras clave: Cardiaco, Colon, Esquirlas, Esquirlas penetrantes, Informe.

\section{BACKGROUND}

Penetrating missiles to the heart is a severe and frequently lethal form of trauma, with a mortality rate of 77 to $81 \%{ }^{1,2}$ Obviously, this high mortality is due to one or more of the following: The disturbed cardiac dynamics, the formation of cardiac tamponade and the torrential hemorrhage that may follow. Many patients succumb to their injury at the scene. Those who survive to reach the hospital, have a chance to remain alive if properly managed and received a timely intervention in appropriate centers. ${ }^{2}$

\section{CASE REPORT}

A 29-year-old male soldier presented to our hospital after sustaining an explosive injury in the war zone. He was received in a stable condition, with a wound in the left shoulder, a small wound in the right iliac fossa, and another in the central chest. Initially, he was managed in a peripheral hospital, from there he was referred to us.

On examination, his vital signs were found stable and, apart from the above-mentioned wounds, his chest and heart examinations were also normal. Abdominal examination showed tenderness around the wound, otherwise there was no undue tenderness or rigidity.

His hemogram showed hemoglobin of $10.5 \mathrm{gm} / \mathrm{dL}$ (reference range 12116), with normal white blood cells and 


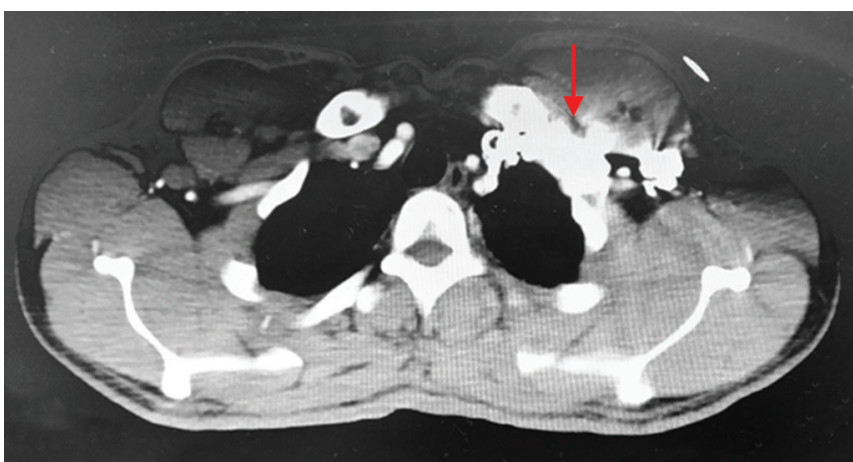

Fig. 1: Computed tomography of the chest showing heavy load of shrapnel in the left shoulder and apex of left chest (red arrow)

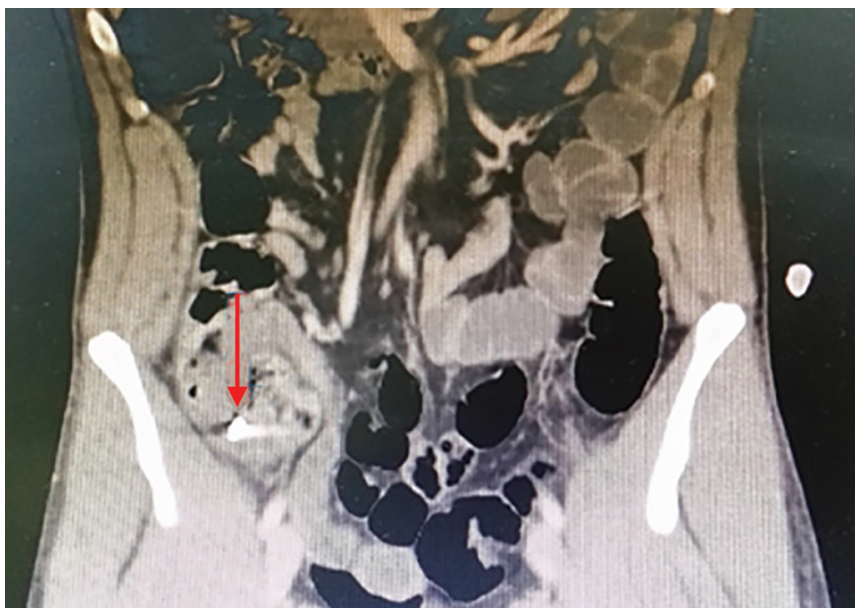

Fig. 3: Computed tomography of the abdomen (sagittal view) showing shrapnel lodging in the caecal region (red arrow)

platelet counts. Other blood works, including liver and renal values, were normal apart from marginally raised serum amylase and lactic acid dehydrogenase.

Computerized axial tomography (CT) scan showed heavy load of shrapnel in the left shoulder and apex of left chest with no hemo or pneumothorax, shrapnel in the right iliac fossa, and another in the heart (Figs 1 to 3 ). Diagnostic transthoracic echo (TTE) located the shrapnel in the interventricular septum with minimal pericardial effusion.

Intravenous antibiotics were started and the shoulder wound was debrided with extraction of the accessible shrapnel. After brief deliberation between the general and cardiac surgeons, a decision was taken to explore the abdomen first. The operation started by laparoscopy, where two opposing hematomata were seen, one in the lateral abdominal wall, and another in the external aspect of the cecum. The cecum was mobilized to inspect its entire surfaces and no shrapnel were found in the area. For better evaluation and to avoid missing a posterior colonic penetration, a decision was taken to convert to laparotomy. The right colon was mobilized; the cecal hematoma was explored to identify a small penetrating

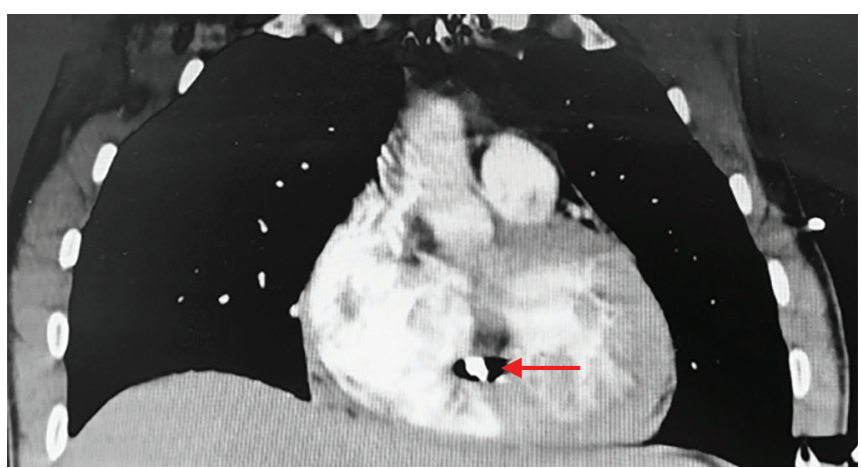

Fig. 2: Computed tomography scan of the chest (coronal view) showing shrapnel lodging in the interventricular septum of the heart (red arrow)

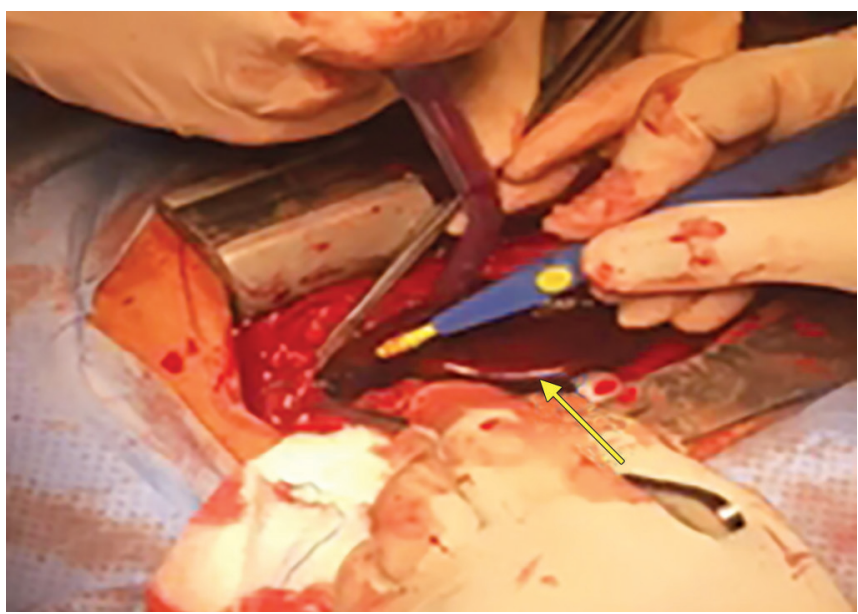

Fig. 4: View after midline pericardiotomy. Big clot (yellow arrow) covering the entry site in the right ventricle

wound in the lateral cecal wall. The cecum and ascending colon were palpated to locate the shrapnel, which was identified with difficulty, lodging in the cecal tissues few centimeters from the entry wound. A forceps was introduced through the perforation and managed to extract the shrapnel. Limited right hemicolectomy, including the lower half of the ascending colon, was performed with ileocolic anastomosis. Two suction drains size 19 were inserted, one in the pelvis and another adjacent to the anastomosis, and the abdomen was closed.

Twelve hours later, open heart surgery was performed. The chest was entered through a median sternotomy incision, and the pericardium was opened in the midline. Soon following this, a big clot was found covering the entry point of the shrapnel at the anterior wall of the right ventricle (Fig. 4). Fortunately, this clot averted a lethal cardiac tamponade. Without removing the clot, a full dose of heparin was given and the aorta was cannulated with a 20 French aortic cannula. A 30 French venous cannula for the superior vena cava and a 32 French cannula for the inferior vena cava, were then inserted.

Two tapes were passed around both cavae. Once the patient was fully cannulated, cardiopulmonary bypass 


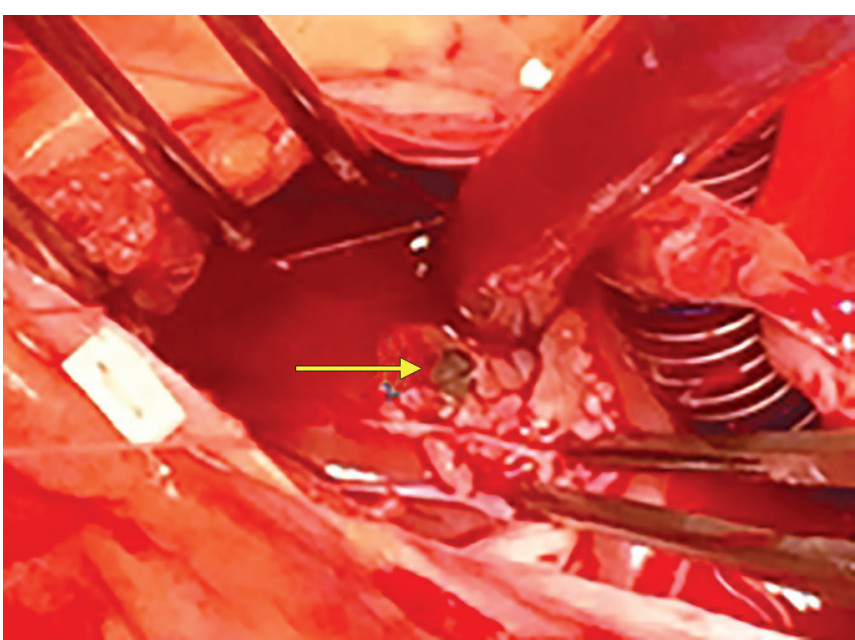

Fig. 5: Impacted shrapnel in the interventricular septum, behind the septal leaflet of the tricuspid valve (yellow arrow)

was started and the clot from the right ventricle was then removed. At this point, the entry site was seen in the right ventricle near the right coronary artery. Following this, the aorta was cross-clamped and antegrade cardioplegia was given. After arrest, tapes around both cavae were tightened and right atriotomy was done.

There was no lesion inside the right atrium but, guided by echocardiography, we found a metallic particle around $1 \mathrm{~cm} \times 0.5 \mathrm{~cm}$ lying inside the muscular part of the interventricular septum, just behind the septal leaflet of the tricuspid valve (Fig. 5). The particle was removed (Fig. 6) and the interventricular septum was repaired with 4-0 prolene in two layers. Another 4-0 prolene suture over a pledget was used to close the shrapnel entry point in the right ventricle (Fig. 7). The patient was weaned off the cardiopulmonary bypass successfully with minimal support. Transoesophageal echocardiogram, done in the operation room, showed no tricuspid regurgitation or residual ventricular septal defect. The patient was transferred to the intensive care unit in a stable, but still critical condition.

The postoperative period was uneventful, and in due course, the patient was shifted to the regular ward. Few days later, he was discharged in a good condition (Fig. 8).
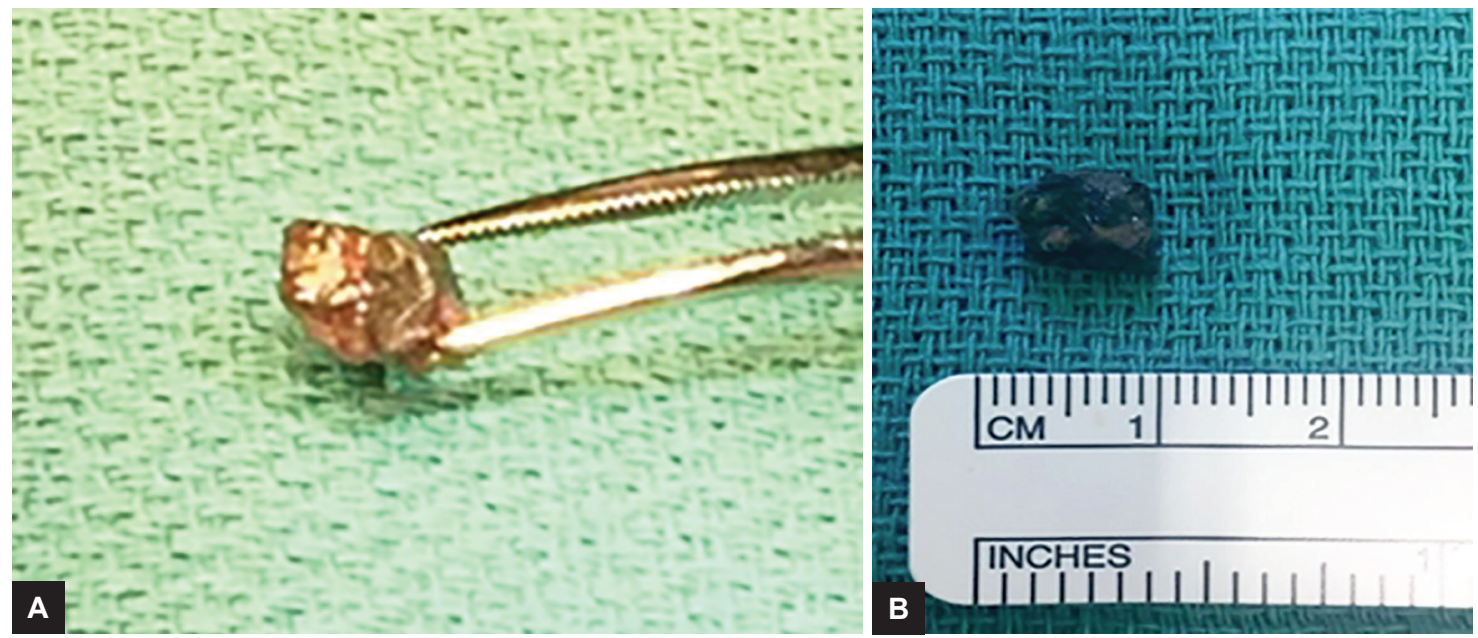

Figs 6A and B: (A) Removed shrapnel; and (B) it measured about $1 \times 0.5 \mathrm{~cm}$

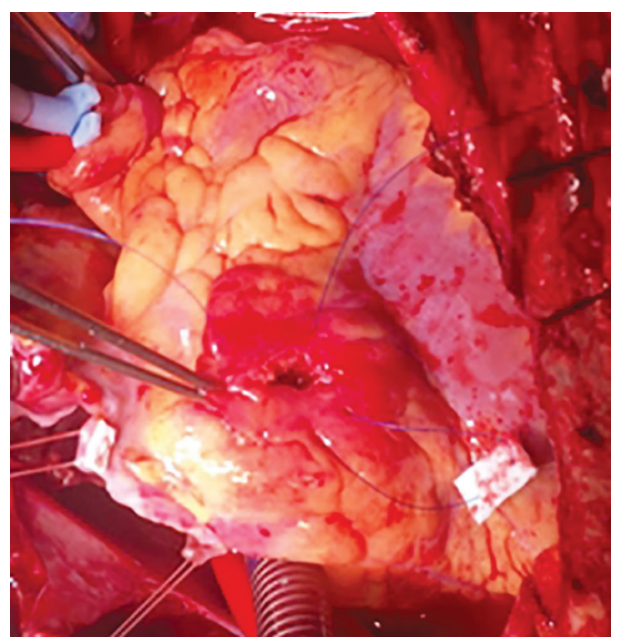

Fig. 7: Entry site in the right ventricle near the right coronary artery. Closure of the wound over a pledget

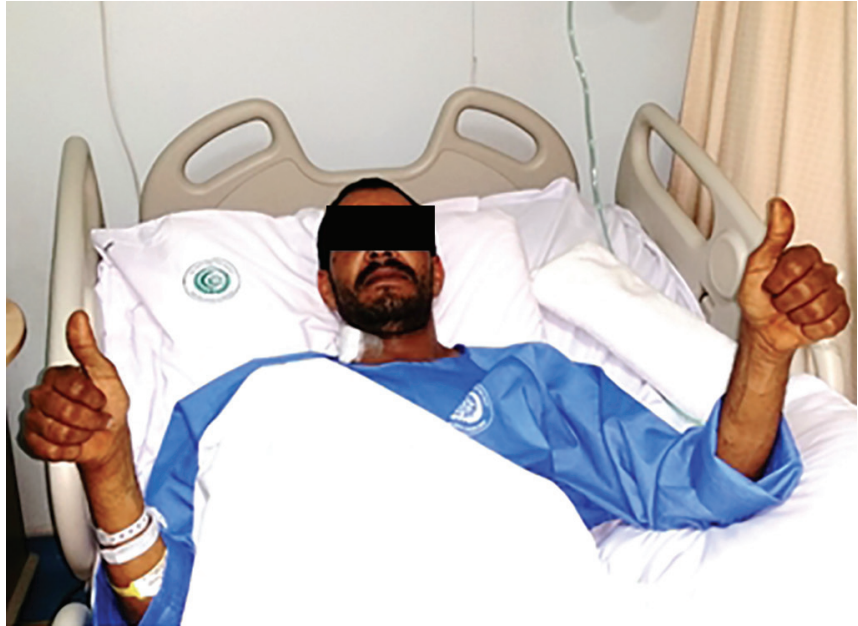

Fig. 8: Patient ready for discharge in good condition 


\section{DISCUSSION}

Due to its specialized nature, penetrating trauma to the heart is a lethal event in the vast majority of cases. The patient succumbs to either derangement of the cardiac dynamics, formation of a cardiac tamponade, or the torrential hemorrhage which follows. Making a narrow escape from such tragic event needs, in addition to extreme luck, proper management in a specialized center.

Understandably, the need for emergency surgical intervention for penetrating cardiac injuries has been stressed. ${ }^{3,4}$ However, a large review of cardiac missile injuries was conducted by Symbas et al. ${ }^{5}$ In their review, a total of 246 missiles in 225 patients were included. The missiles were either bullets, shrapnel or pellets. Some missiles were left in place while others were removed with mortalities incurred on both ways. They suggested that the management of cardiac missiles should be tailored to the individual patient, according to the clinical picture, missiles characteristics, and expertise available. Additionally, a conservative approach could be adopted in certain situations. In this regard, a conservative management of a retained intracardiac missile has been relatively recently reported for a patient who had a $2 \mathrm{~cm} \times 2 \mathrm{~mm}$ intracardiac missile following a mortar blast. ${ }^{6}$ Another large review involving 285 patients with battle cardiac injuries, identified factors affecting survival. Young age, early transportation to a specialized center, hospital setup, type of missile, early intervention, hemodynamic stability at presentation and type of the cardiac lesion, are good prognostic factors. Concerning the site of trauma, coronary vessel injury had the best survival chances, followed by atrial wounds and the lowest was left ventricular wounds, as it causes pump failure. ${ }^{4}$

In our patient, the shrapnel was shown on CT and TTE, to lodge in the interventricular septum, but we were not sure of the depth of penetration and how stable the missile was. For that reason and for fear of future dislodgement and embolization, we decided to extract it.

Although certain cardiac injuries may be repaired without cardiopulmonary bypass, for example, in injuries involving the anterior surface of the ventricles in stable patients, cardiopulmonary bypass was needed in our patient to remove the shrapnel from inside the heart, and not from the surface.

Undoubtedly, the presence of multiple injuries, adds more complexity to the situation. In addition to his left shoulder and upper chest injury, which needed only local care, our patient had two penetrating injuries, one to the colon and the other, the more lethal one, to the heart. Despite these injuries, he presented in a hemodynamically stable condition, to allow staged procedures to be performed. The debate was what to tackle first, the colonic or cardiac injury. Starting with the cardiac injury would necessitate putting the patient on full anticoagulation to be able to start the cardiopulmonary bypass, which would render subsequent laparotomy hemorrhagic and prone to bleeding complications. For this reason, laparoscopy, which was converted to laparotomy, was performed first to tackle the colonic injury. At the end of the procedure, all bleeding points were carefully secured and intra-abdominal drains were left behind, in anticipation for any possible hemorrhage, following the full anticoagulation necessitated by the cardiac surgery. In this regard, laparoscopy is emerging as a minimally invasive tool in the management of penetrating abdominal trauma, with a sensitivity, specificity and accuracy approaching $100 \% .^{7-9}$ Its merits may include avoidance of a nontherapeutic laparotomy and a long laparotomy wound with its attended complications. In our patient, the necessity for therapeutic anticoagulation and our desire to decrease the overall severity of trauma to which the patient was subjected, were strong incentives to start the abdominal part of surgery by laparoscopy. Unfortunately, this did not work and conversion to laparotomy was needed.

Injury to the colon by fragments of an explosive device, may be direct, if it lies in the trajectory of the missile, or indirect. In the later condition, the colon, though lying at a distance from the trajectory, will be injured by the energy transferred from a high velocity missile, ${ }^{10}$ a phenomenon known as cavitation effect. ${ }^{11}$

Depending on the need for resection, colonic injuries are generally divided into two categories: (1) Destructive and (2) nondestructive. Guided by this categorization, treatment options are primary repair, resection anastomosis with or without fecal diversion, and resection with fecal diversion. Little or no high quality evidence is available; to guide the choice of the surgeon and sound judgment is certainly of the utmost importance. ${ }^{12}$ Apparently, our patient had a nondestructive colonic injury, which could be repaired primarily. ${ }^{10}$ However, the inability to assess the integrity of the posterior colonic wall opposite the site of perforation, with confidence, and for fear of a delayed perforation with its consequences on this fragile patient with additional cardiac injury, we opted to perform a formal limited right hemicolectomy. Additionally, primary repair of colonic wounds sustained in the battlefield, has been traditionally discouraged by the military surgeons, although this has been recently questioned. ${ }^{13}$ Among other risk factors, this paradigm has been ascribed to the cavitation phenomenon associated with high-velocity war injuries, with its effect of the blood vessels and colonic wall in the nearby area of the perforation. $^{13}$ 
Our patient was lucky enough to have a clot formed at the site of missile penetration into the heart. This prevented the formation of a lethal cardiac tamponade or exsanguinating hemorrhage. During surgery and to keep the situation under control, the clot was removed only after applying the cardiopulmonary bypass and this certainly helped to achieve a successful outcome.

\section{CONCLUSION}

For the successful management of penetrating cardiac missiles associated with other injuries, careful planning and cooperation between the specialties concerned, are of paramount importance. If the patient is stable enough, performing the abdominal part of surgery first, may avoid the subsequent complications of the full anticoagulation needed during or after the cardiac surgery. Although it is up to the surgeon's assessment, associated colonic injuries may be better managed with limited resections, rather than primary repair, to avoid the consequences of late breakdown or missing an injury in the apposing colonic wall, in these fragile patients.

\section{CLINICAL SIGNIFICANCE}

Critical thinking is needed to prioritize which injuries to deal with first, in patients with near lethal injuries.

\section{REFERENCES}

1. Tyburski JG, Astra L, Wilson RF, Dente C, Steffes C. Factors affecting prognosis with penetrating wounds of the heart. J Trauma 2000 Apr;48(4):587-590.
2. Degiannis E, Loogna P, Doll D, Bonanno F, Bowley DM, Smith MD. Penetrating cardiac injuries: recent experience in South Africa. World J Surg 2006 Jul;30(7):1258-1264.

3. Gao JM, Gao YH, Wei GB, Liu GL, Tian XY, Hu P, Li CH. Penetrating cardiac wounds: principles for surgical management. World J Surg 2004 Oct;28(10):1025-1029.

4. Zakharia AT. Analysis of 285 cardiac penetrating injuries in the Lebanon war. J Cardiovasc Surg (Torino) 1987 JulAug;28(4):380-383.

5. Symbas PN, Picone AL, Hatcher CR, Vlasis-Hale SE. Cardiac missiles. A review of the literature and personal experience. Ann Surg 1990 May;211(5):639-647.

6. Lundy JB, Johnson EK, Seery JM, Pham T, Frizzi JD, Chasen AB. Conservative management of retained cardiac missiles: case report and literature review. J Surg Educ 2009 Jul-Aug;66(4): 228-235.

7. Uranues S, Popa DE, Diaconescu B, Schrittwieser R. Laparoscopy in penetrating abdominal trauma. World J Surg 2015 Jun;39(6):1381-1388.

8. O'Malley E, Boyle E, O'Callaghan A, Coffey JC, Walsh SR. Role of laparoscopy in penetrating abdominal trauma: a systematic review. World J Surg 2013 Jan;37(1):113-122.

9. Koto MZ, Matsevych OY, Motilall SR. The Role of Laparoscopy in penetrating abdominal trauma: our initial experience. J Laparoendosc Adv Surg Tech A 2015 Sep;25(9):730-736.

10. Webster C, Mercer S, Schrager J, Carrell TW, Bowley D. Indirect colonic injury after military wounding: a case series. J Trauma 2011 Nov;71(5):1475-1477.

11. Klein Y, Shatz DV, Bejarano PA. Blast-induced colon perforation secondary to civilian gunshot wound. Eur J Trauma Emerg Surg 2007 Jun;33(3):298-300.

12. Johnson EK, Steele SR. Evidence-based management of colorectal trauma. J Gastrointest Surg 2013 Sep;17(9):1712-1719.

13. MacFarlane C, Benn CA. Primary closure of battle wounds of the colon: is it an option for the military surgeon? J R Army Med Corps 2001 Jun;147(2):179-182. 